\title{
The Malaysian EFL Education: A Brief Historical Review and Literacy Issues
}

\author{
Harison Mohd. Sidek ${ }^{1, *} \&$ Wahiza Wahi ${ }^{2}$ \\ ${ }^{1}$ Faculty of Major Language Studies, Universiti Sains Islam Malaysia, Malaysia \\ ${ }^{2}$ Pusat Citra Universiti Universiti Kebangsaan Malaysia, Malaysia \\ *Correspondence: Faculty of Major Language Studies, Universiti Sains Islam Malaysia, Malaysia. Tel: \\ 6-016-331-4043. E-mail: harison@usim.edu.my
}

Received: December 24, 2017 Accepted: January 9, 2018 Online Published: January 23, 2018

doi:10.5430/sass.v5n1p21

URL: https://doi.org/10.5430/sass.v5n1p21

\begin{abstract}
Hailed as a lingua franca, the English language maintains its significance at the global level and due to such status, it has been made a mandatory subject at the elementary, secondary and tertiary institutions in Malaysia. This paper presents the review of English literacy in terms of its historical path and its status as a second language (EFL) issues within the Malaysian educational context. Document review was conducted for the study to find out the Malaysian English literacy historical path. A library research on mainstream journals was carried out to find out EFL literacy issues in Malaysia. The historical review reveals that the mandatory inclusion of the English literacy in the school and higher institutions' curriculum could be traced back as a linguistic culturalization effect of the British colonization. The review also indicates that the pattern of inclusion of the English literacy in the Malaysian educational system seems to be developmental in nature but with some patterns of consistency at the initial stage of its inclusion. With regards to the EFL literacy issues, the review shows that the shifting from the English to the Malay medium in public schools could be inferred as one of the root causes of the emergence of issues in the EFL literacy amongst Malaysian learners. The outcomes of the review have implications on English literacy policy, future revisions of English literacy curriculum to alleviate the current EFL literacy issues and to increase its effectiveness in EFL teaching and learning in the Malaysian context.
\end{abstract}

Keywords: English literacy; EFL; curriculum; Malaysian educational policy; historical review

\section{Introduction}

The English language has been regarded to play a significant role in within the domains of economic, politics and social; it is indeed the language of choice in the marketplace, and a universal medium of business communication worldwide - a common denominator in international affairs (e.g., Cope \& Kalantzis, 2000; Phillipson, 2009). Therefore, many non-English speaking countries promote English proficiency as an effort toward modernization and internalization (e.g., O'Neill \& Chapman, 2015; Pennycook, 1994; Tsui \& Tollefson, 2006) and so is Malaysia. For the period beginning from the $18^{\text {th }}$ century to present, Malaysia demonstrates an explicit track record in valuing the EFL instruction. Prior to 1983, the English language had been the medium of instruction in Malaysian schools. Despite the English language being phased out as the medium of instruction in Malaysian schools beginning from 1983 and replaced by the national language (Bahasa Malaysia), the language continued to be valued by making it a mandated subject in the Malaysian educational curriculum from elementary school to the university level. Despite the emphasis on the English language in the Malaysian setting, it is a phenomenon of why there is a persistent literacy issues in English as a second language (EFL). As reflected by the literature, EFL literacy issues are commonly investigated surrounding its core elements such as instructional practices and learners' literacy proficiency factors. Hitherto, there has been hardly any study that attempted to unravel the root cause of EFL literacy issues in connection to the shift in language policy. If there is such study, it might not be made available in the mainstream publications. Hence, a review was called for the Malaysian EFL education in terms of its policy historical path and how it might have its share in EFL literacy issues within the Malaysian educational context. The documents reviewed in this study were conducted using the Malaysian Education Ministry's documents such as 
Razak Committee Report (1955), Education Ordinance (1957), Rahman Talib Report (1960), Course of Studies Regulation 1956 and National Language Act (1971). To identify EFL literacy issues, a library research on mainstream journals was carried out. Prior to reviewing the historical pathway of EFL education in Malaysia, the Malaysian EFL educational context will first be described as a complement to the review to provide a better understanding.

\subsection{The Malaysian EFL Educational Context}

Within the Malaysian educational context, the formal EFL instruction commences with elementary education and extends from Year 1 to 6 or the American educational system equivalence of Grades $1^{\text {st }}$ to $6^{\text {th }}$; that is from age 7 to 12. The English language is a compulsory subject at each grade level and this subject is one of the subjects assessed in the norm-referenced test known as Ujian Penilaian Sekolah Rendah (Elementary School Assessment) at the end of the $6^{\text {th }}$ Grade in elementary school.

Secondary education in Malaysia begins from the age of 13 to 17 , from Form 1 to Form 5 or Grades $7^{\text {th }}$ to $11^{\text {th }}$ according to the American high school standard. EFL instruction at the secondary school level is taught formally as a mandated subject from Form 1 to Form 5. Before exiting the secondary school, students have to take a standardized norm-referenced examination known as Sijil Pelajaran Malaysia (SPM) or Malaysian School Certificate. Students' performance on the English language subject is not a criterion for entry at the university level. However, to qualify for entry to the Malaysian public universities, applicants must meet the minimum requirement of the English language proficiency assessed in the Malaysian University English Test (MUET). This national level test is a criterion-referenced test administered by the Malaysian Examination Syndicate. Figure 1 demonstrates the graphic representation of current EFL education in Malaysia.

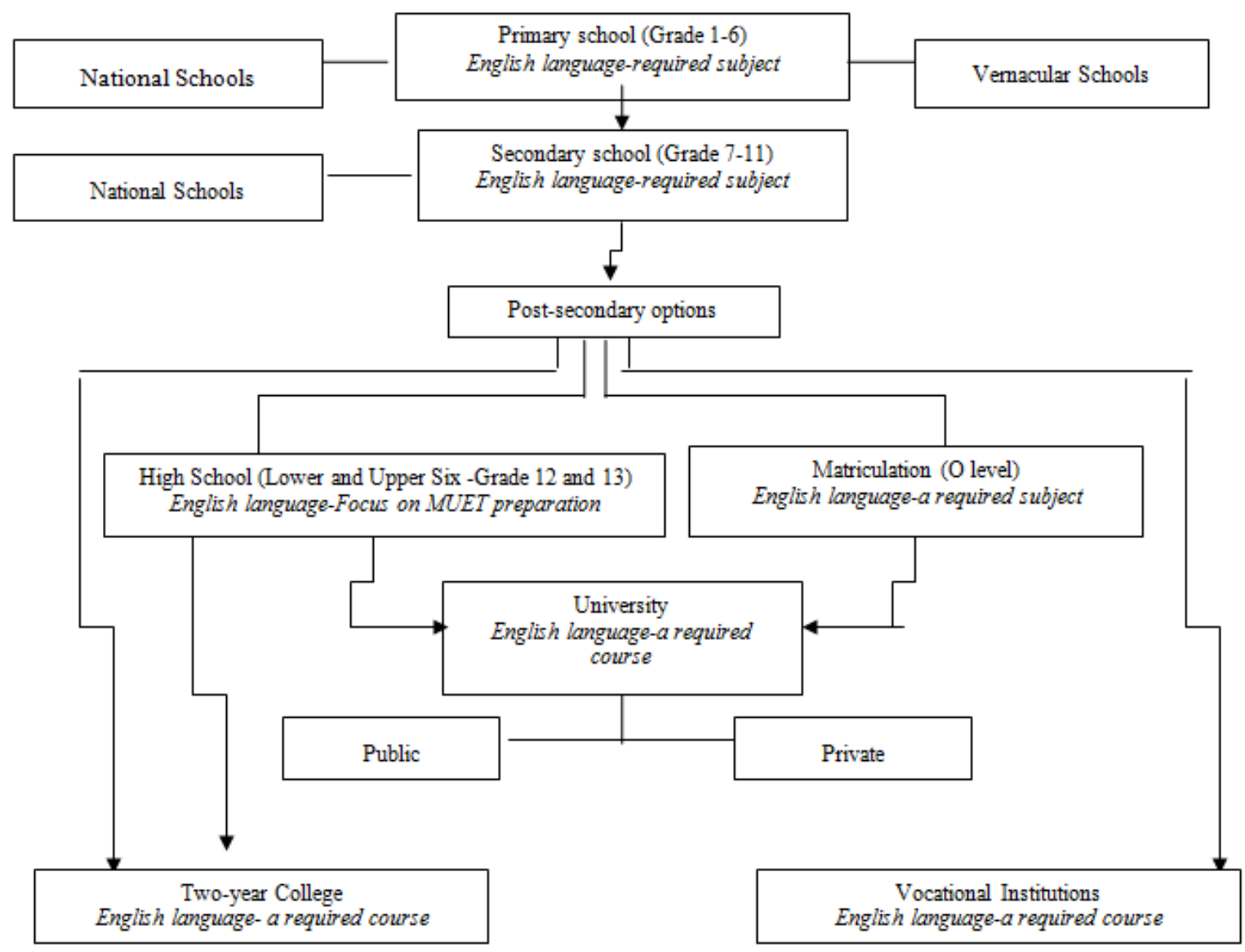

Figure 1. Malaysian Educational System and the EFL Requirements 
Statistically, in total, there are currently more than 31 public and private higher institutions (www.etawau.com/edu/IndexUniversity.htm). With regards to 4-year public higher institutions of which the medium of instructions is English and Arabic, there are only two of such institutions in Malaysia. At these institutions, all courses are delivered in the English language with the exception for the Islamic studies courses. In majority, private higher institutions use the English language as the medium of instruction. Since the English language is highly valued in the Malaysian educational system, the English language has been included in the curriculum as a required subject at all educational levels.

\section{A Review of Malaysian EFL Educational Policies}

Before reviewing the historical path of Malaysian EFL educational policies, it is important to know the realm of decision-making for language policy with the Malaysian context. There are two types of language policy decision-making; bottom-up and top-down. According to Gill (2006), the Malaysian language policy can be described as "top down" instead of "bottom up" (Kaplan \& Baldauf, 1997, p. 196). The language policy decision-making in Malaysia is considered as top-down because it comprises "people with power and authority who make language-related decisions for groups, often with little or no consultation with the ultimate language learners and users" (Kaplan \& Baldauf, 1997, p. 196). Such nature of the decision-making system for language planning still persists until today.

Reverting back to history, as early as the British colonization in the $19^{\text {th }}$ century, the English language had begun to be formally taught (Powell, 2002) as a mandated subject in elementary and secondary schools (Course of Studies Regulation 1956, II). Nonetheless, according to Muthusami (1978), the English language educational policy was rather inconsistent during the period of British colonization because of the British divide and rule governance. The Malay ethnicity during this era had an adverse perception of the English education as they related the language with Christianity (Asmah, 1996). Nevertheless, during the early of $20^{\text {th }}$ century, due to the thriving of crop agriculture, the rate of employment for the Malays in the government sector increased rather significantly. As a result, the Malays' perception of the English language began to shift more favourably that they demanded for better English education from the British for the purpose of employment.

Prior to acquiring independence, the status of the English and Malay languages in Malaysia was equal. Razak Committee (1955) emphasized the significance of implementing a single-system education as well as a standardized instructional language. On the contrary, the 1952 education ordinance suggested for the public primary schools to be either a Malay medium or English medium school. Even though primary schools had to be Malay medium schools, the language policy was more lenient at the secondary school level of which the schools were given the liberty to choose whether to be a Malay or English medium school. Nonetheless, on the verge of independence, the existing government felt that implementing a bilingual educational system may result in divided citizens. Upon such realization, the Malay medium and vernacular Chinese and Tamil primary schools were implemented with the maintenance of the English language subject in the curriculum as proposed by the Education Ordinance (1957). Upon independence, Malay was declared as the national language while English was still used officially as stated in the 1957 constitution (Foo \& Richards, 2004).

The emergence of the Rahman Talib Report in 1960 resulted in most Chinese secondary schools to shift to the English language medium upon the required choice to either implement the Malay or the English language as a medium of instruction. After a decade of independence, for the purpose of sustaining educational standards (Asmah, 1979), the English language was maintained as a mandated subject at all school levels while the medium of instruction for secondary school was shifted to the Malay language (National Language Act, 1967. This shift was further strengthened by the National Language Act (1971) by making the Malay language as a leading role with the English language holding secondary role in the Malaysian educational domain (Heng \& Tan, 2006).

"English was relegated to the position of a second language in the education system, a language which is compulsory to take, but not to pass, for all Malaysian school children" (Gill, 2006, p. 84). As the English language was given a lesser status, it yields a domino effect of a marginalization in the importance of the English language as it is not a determinant for entry at a higher educational level. In effect, in the early 1980s, a major shift from English medium instruction to Malay medium instruction occurred among all schools and universities except for the International Islamic University of Malaysia that maintains the English language as its medium of instruction. "A credit in English was made unnecessary as a condition for university entry in 1988; and in 1995 it became official that English was not a compulsory subject to obtain the Secondary School Leaving Certificate (Sijil Pelajaran Malaysia) after 11 years of school education" (Heng \& Tan, 2006, p. 309).Adversely, within more than the past three decades, the 
English language proficiency among students at every school level has been declining resulting in an increasing rate of unemployment among university graduates (Lee, 2004).

The adverse economic impact due to the incompetency in the English language had reached the level that raised concern in the Malaysian context. In accordance, in 1990s, language policy makers in Malaysia began to pay their attention on this issue (Ridge, 2004). Having the stability in politics, the Malaysian government made an effort to reinstate the English language competency among students using its educational system as a vehicle. The Malaysian fourth prime minister, Mahathir Mohamad who governed Malaysia from 1981-2004, realized that the English language had been sidetracked in the Malaysian educational system (Mahathir, 1986) despite the fact that the English language should be acquired "for its utilitarian value, for employment and for guaranteeing access to the science and technology of the West" (Gopinathan, 2003, p. 21). Such notion suggests the importance of the English language as a tool for success in various domains.

Although the native language carries an integrative value in countries of which English is not the native language, the English language possesses a more significant instrumental value especially within the economic domain. Despite this fact, according to Powell (2002), the statistic of incompetent students in the English language became more prominent. Ironically, such unfavourable ascending statistic continues despite the effort by the Ministry of Education increasing the instructional hours for the English language subject (Kalaverny, 1986; Wahi, 2015) with the aim to heighten the English language proficiency among students. The Malaysian government invested further effort in the mid-1990s through the implementation of the shift of instructional medium from Malay to English at the university level for courses in science, medicine, engineering and law (Powell, 2002). According to Ridge (2004), the same policy was implemented for courses in technical areas. According to Asmah (1996), University of Malaya, the oldest university in Malaysia, a high level of English language attainment for entrants. In contrast, for three-year diploma programs, students in technical disciplines such as engineering are merely required to obtain a pass in the English language (Shukor et al., 1993). At the certificate level offered by post-secondary institutions, attainment in the English language is not a requirement. Minimum or no requirement for the English language attainment marginalized the importance of the English language which resulted in students losing their motivation to acquire the English language at the post-secondary educational level.

A new English language policy emerged in 2002 as the outcome upon the realization of the importance of the English language for knowledge-based disciplines with the implementation of the Malaysian University English Test (MUET) mandated to students at the pre-tertiary level. As a norm-referenced test, the MUET is a determinant of entrance qualification for enrollment at Malaysian public universities. Heng and Tan (2006) perceived MUET as:

"Providing the essential continuity in the exposure and use of English for students leaving the general school system. In other words, students who aspired to further their studies in local tertiary institutions would sit the MUET in order to qualify for entry. This gave the impetus for English to play a bigger role in the national educational system, even though the MUET was limited to the promotion of general academic English" (p. 310).

Since MUET is mandated as the entry or graduation requirement at the university level, such effort assists the sustenance of the importance of the English language at the university level (Heng \& Tan, 2006). Since many students failed to achieve the minimum requirement on MUET at the pre-tertiary stage, they were still allowed to enroll upon meeting the other requirements. In such situation, MUET becomes an exit test since it is required for students to qualify for graduation. There is no limit imposed in taking MUET. Students can make as many attempts until they meet the minimum requirement on the test. The implementation of MUET as a ticket for entry to higher institution suggests a continued emphasis on the English language in the Malaysian educational context.

As an effort to increase the competency in the English language among Malaysian university graduates, a new language policy using a pragmatic approach was implemented in the year 2003in which the medium of instruction for science and mathematics subject at the junior primary and secondary school levels. Simultaneously, a genre-specific approach was implemented with the introduction of English for Science and Technology (EST) for upper secondary school Form Four or $10^{\text {th }}$ Grade students. This new subject was taught alongside the general English language subject. The new subject EST, was a part of the implementation of the new English language policy by the Ministry of Education (MOE). The new policy was an outcome of a study conducted by the MOE, which study showed that unemployment issues with regards to the private sector among graduates from Malaysian universities was due to their poor command of English (Star, 29 June 2003 as cited in Gill, 2005).

Besides schools, the new language policy also affected the Malaysian public universities. "All public universities will also have to switch to English as the medium of instruction in science and technology subjects in 2005 when the 
first batch of STPM students taught in English enter university" (Sunday Star, as cited in Kaur \& Thiyagarajah, 1999). Nonetheless, there is no evidence insofar which indicates that adding English for Science and Technology (EST) and teaching science and mathematics in English has helped improve students' English language proficiency and competency especially in EFL literacy. Although the English language is made a mandatory subject at all educational levels, even with the addition of the EST subject at school level, many past studies (e.g., Faizah, Zalizan, \& Norzaini, 2002; Kaur, 2006; Wahi, 2015) have reported that Malaysian learners continuously facing difficulties in the English language.

A study by Wahi (2015) reveals that many undergraduate students perceive that schools are the pivotal entity responsible for their weak foundation in English language literacy. Deficits in English begin at primary school and then continue throughout their secondary and tertiary level; these deficits have continuously jeopardised their overall academic achievement and exacerbated their resistance to English. The study also contends that many Malaysian students see English as a language that fits neither the description of a second language nor that of a foreign language. In fact, it is to them an 'alien language' that they must learn in schools, a completely outlandish language, unfamiliar in the contexts of their mother tongue languages.

Hence, upon the historical review of the EFL educational policy, it is important to review EFL literacy issues to find out if it might have some possible connections with its historical language policy and planning within the Malaysian context.

\section{EFL Reading Issues in The Malaysian Educational Context}

This section discusses the macro and micro EFL literacy issues within the Malaysian setting. Besides getting the general picture of EFL literacy issues at the macro level, it is important to provide the meta issues of EFL literacy at the micro level in order to show how the EFL planning and policy designs the nature of EFL literacy instructional practices.

In general, many studies had been conducted in the Malaysian contexts concerning issues in EFL education (e.g., Abdullah \& Sidek, 2012; Baharun et. Al., 2016; Saad et al., 2016a; 2016b; Sidek, 2009, 2010b, 2011, 2012a, 2012b, 2012c, 2012d, 2013a, 2013b; Sidek \& Abdullah, 2013; Sidek, Abdullah \& Rahim, 2013b; Sidek, Abdullah, Rahim \& Mohamed, 2014; Sidek \& Rahim, 2013, 2014, 2015; Sidek et al., 2016a, 2016b). One prominent EFL issue within the Malaysian setting is literacy; a phenomenon that is frequently reasoned to be connected to EFL instructional practice of which practice is directly influenced by the curriculum that is commonly designed based on a close mapping with the fundamentals of language planning and policy.

As far as EFL literacy instruction is concerned, many (e.g., Nambiar 2005; Ponniah, 1993; Sidek, 2010a; Che Musa et al., 2012) have reported that the format of IRE (initiation-response-evaluation) is a common EFL reading instructional practice at the Malaysian public secondary schools. This instructional approach involves students reading silently, teacher asking questions, students responding and the teacher evaluating either the response is right or wrong. The teaching of reading in the Malaysian school is commonly concentrated on lower level processing skills such as word recognition (Ponniah, 1993). Nambiar (2005) concluded that such reading comprehension instructional approach does not facilitate students with the appropriate understanding of the entire text. Since the Malaysian educational system is highly examination-based oriented, the teaching of EFL reading comprehension tends to be affected by such nature that instructional goals are often directed to train students with strategies that facilitate them to be good reading comprehension test takers with regards to getting the right answers (Nambiar, 2005).

In addition, Nambiar (2005) depicts a typical EFL reading instruction in Malaysian classrooms:

"Reading lessons are often conducted in a mechanistic manner with learners having to read a text first, underline difficult words and then use a dictionary to source the meaning of each word. Then the comprehension questions are used to identify the important ideas in the text. A very popular method employed in school is to get learners to identify main ideas in each paragraph and more often than not these main ideas are usually in the first few lines of each paragraph."

(http://www.google.com/search?hl=en\&q=radha+nambiar-gopal)

As described above, such reading task demonstrates lack of cognitive demand in the EFL literacy training at the secondary school level. This isnot in alignment with the required cognitive demand in language and academic 
reading tasks with which students commonly engage in at the university level. According to Shih (1992), a traditional reading comprehension instruction normally merely involves the belief that breaking the text into a smaller segments would facilitate understanding of information without teaching the students to make connections of the information in the segments as an integrated whole. LeVasan (1983) stated that within the Malaysian context, EFL reading assessments highly influence EFL reading instructional practices. LeVasan also added that since EFL comprehension assessments commonly includes70 percent of direct reference type, EFL reading teachers are inclined in concentrating on similar reading tasks. Teaching students to primarily process direct reference type merely training them to get "the right answer", which teaching practice reflects the Initiation-Response-Evaluation or the IRE format. The IRE method is known as a traditional reading comprehension instructional method considered as rather ineffective in training students to build the author-intended meaning from texts (Beck \& McKeown, 2006).

Due to such training, students' ability is limited to performing short-answer questions as well as literal recalls. As such they are unable to do inference and build connections among text ideas when processing academic reading texts (e.g., Kanagasabai, 1996; Nambiar, 2007; Ponniah, 1993 Wahi et al., 2012). The adverse impact of such inability is even more prominent for students at the universities of which the medium of instruction is in the English language. Besides not performing well on EFL assessments, EFL reading inability could also affect their overall academic performance (e.g., Che Musa, et al. 2012; Ramaiah, 1996; Faizah, Zalizan, \&Norzaini, 2002 Wahi et al., 2012). With such an impact of the current EFL literacy instructional practice, it is critical to have a retrospective of the entire EFL educational process that begins from the setting of EFL educational planning and policy that shapes the characteristics of the EFL curriculum. Merely focusing in amending EFL literacy at the instructional practice level would only translate to dwelling on the problem without addressing the root cause of the problem.

Kaur and Thiyagarah (1999) studied the perception of university students in the English Language and Literature Studies program on their EFL reading comprehension ability. The finding shows that 48.6 percent of the respondents rated their EFL reading comprehension ability when reading materials in English in general as well as literary works as 'not very efficient'. Inferring from the finding in this study, Malaysian universities students merely have developing academic readiness with regards to reading in the English language due to the absence of competency in EFL literacy. As contended by some researchers (e.g., Abu Hasan, 2008; Kaur \& Thiyagarah, 1999; Mohd. Noor, 2006; Sidek, 2010c; Wahi et al., 2012; Wahi 2013), to meet academic demand at the university level in Malaysia, having EFL reading comprehension skills is a crucial factor. Hence, students' ability to process and comprehend English language texts are important correlates to academic literacy and achievement. Again, retrospectively, the EFL literacy issues that occur at the higher institution level is the outcome of a less efficient EFL educational planning and policy which serves as a foundation of a larger EFL educational structure.

As mentioned earlier, the change in EFL educational policy at its historical stage in honouring the native language has its longitudinal share affecting the mindset or perception of EFL learners towards EFL literacy. In Sidek's (2009) study, an EFL reading attitude survey was conducted at a Malaysian public university. One of the selected university's mediums of instruction is English. The most frequent responses are, "Reading in English is a daunting task for me", "Every time I tried to read in English I easily give up because I don't understand most of the words in the text", "I would be very proud if I could finish reading an English text and be able to understand what I read." The findings also show that university students do place importance in reading and understanding well in English even though they do not possess the required EFL reading comprehension skills for academic reading at the university level. Based on her anecdotal experiences at the university level, Mustapha (1995) stated that "many of the so-called "fluent" readers are still incapable of reading for comprehension. The problems become more prominent when they have to read for information and without the teacher close at hand to help them" (p.28). Such data show university students at the Malaysian universities cannot be labeled as self-regulated readers in the English language, a required condition for successful academic reading activities involving materials in the English language. This condition should be of concern and rectification is imperative. Therefore, within the Malaysian's top-down language educational planning and policy context, it is crucial to look back at the fundamental of language planning and policy as an agent at a higher hierarchical level in order to refine a more effective structure as the implementation agent at a lower hierarchical level.

In sum, instructional practice in EFL is very much directly connected to the EFL curriculum of which development and designed are directly shaped by the EFL educational planning and policy. Nonetheless, the correlations among EFL language planning and policy, EFL instructional practice and its outcomes as depicted by EFL learners' have received a rather passing attention, if any. As a result, changes in EFL educational policy from its historical period until present time does not seem to clearly contribute to more favourable impacts in improving the issues in EFL literacy among Malaysian learners; a phenomenon that deserves further investigation. 


\section{Discussion}

The historical review of the Malaysian EFL education has revealed that at the policy level, a major shift in EFL policy occurred in 1967 when the National Language Act was implemented in alignment to the proposition made in the Rahman Talib Report in 1960. All non-vernacular schools had shifted from using English as the medium of instruction to the Malay language or Bahasa Melayu. This implementation resulted in the Malay language being highly emphasized over the English language of which the English language began to be used only when teaching the English language subject. As the emphasis on the Malay language in Malaysian public schools beginning from 1967 grew stronger, the emphasis on the English language became narrowed down to only in the English language class. Other than the English language textbook, textbooks for other subjects were also transformed into the Malay language. Such language planning and policy change can be reasonably inferred to have contributed to an adverse impact to EFL literacy.

Developmentally, the use of the English language amongst teachers and students inside and outside class began to diminish as reflected by the present school context in Malaysia today. The amount and duration of exposure as well as the use of a language plays a role as a proxy of dominance in the rate of language learning (e.g., La Morgia, 2014; Place \& Holf, 2011). In addition, the change in EFL language policy with the goal to uphold the native language has indirectly impacted the people's mindset adversely regarding the importance of the English language. As such, it can be inferred that Malaysian learners began to struggle with the English language which includes EFL literacy as the result of the longitudinal adverse effect due to the shift in language policy, which brought the English language to its new lower hierarchy in comparison to the Malay language that has become dominant in all aspects of formal education.

Due to the significantly less degree in emphasis on the English language, students have been receiving less exposure since instructional time that involves the English language has been prominently reduced in line of the national goal to inculcate the patriotism-based unity among the multi-ethnic Malaysians via the widespread use of the Malay language using education as the platform and a long-term vehicle. Adversely, such one-pronged vision has somehow overlooked the longitudinal impacts on the diminishing rate of students acquiring EFL, which leads to the deterioration of students' performance in the EFL until today. Nowadays, even if students performed well on EFL examinations, they have been reported to not be functional and competent beyond the EFL formal assessment domain (e.g., Mustapha, 1995; Che Musa et al., 2012). The adverse impact is an issue of duration exposure in the formal and informal context within the school boundaries. The duration of exposure in language learning is a critical factor. Perhaps, the EFL policy makers need to revisit this factor and consider its inclusion when refining EFL language planning and policy at the ministerial level. Differentiated effort among the policy makers and practitioners at the school and university levels is called for because such collaboration might enable the formation of a concerted effort that might yield more comprehensive views in pin informing the development of a need-sensitive EFL language planning and policy. Differentiated effort has been reported to have positive impact in producing more efficient outcome (e.g., Ambigapathy et al. 2013; Nambiar et al., 2008). Perhaps the development of such a policy might assist in rectifying the damage caused by the drastic change in EFL status as reflected from the Malaysian EFL education historical review.

Past studies on EFL reading comprehension in Malaysia (e.g., Faizah, Zalizan, \& Norzaini, 2002; Kaur and Thiyagarah, 1999; Ramaiah \& Nambiar, 1993; Ramaiah, 1996; Sidek, 2009, 2010b, 2011, 2012a, 2012b, 2012c, 2012d, 2013a, 2013b; Sidek \& Abdullah, 2013; Sidek, Abdullah \& Rahim, 2013b; Sidek, Abdullah, Rahim \& Mohamed, 2014; Sidek \& Rahim, 2013, 2014, 2015; Sidek et al., 2016a) have shown that the majority of students at Malaysian universities struggle with EFL reading. Struggling EFL readers are often lack of the EFL literacy skills required for academic reading. At the university level, such condition lends to an adverse impact. Hence, within the Malaysian context, despite the longitudinal facilitation of EFL reading comprehension instruction from primary school to secondary school, the majority is university students are still at the EFL struggling readers level. This phenomenon can be related back to the historical shift in language policy in terms of its persisting impact. It can be inferred that language policy is a sensitive affecting factor in the long run for language competence.

\section{Conclusion}

One factor that could be inferred to cause an adverse phenomenon for EFL literacy within the Malaysian setting is the shift of the instructional medium from the English language to the Malay language upon Malaysia gaining its independence. The initial shift in the Malaysian EFL policy and the continual emphasis placed on the use of native language as the medium of instruction across the Malaysian curriculum at all school levels resulted in the digression 
of English language usage and exposure in the educational setting. Such a longitudinal adverse reinforcement of the English language within the Malaysian educational setting resulted in the deterioration of English language learning and competence in general and the EFL literacy in specific. The finding of the review in this study suggests that language planning and policy has its prominent share in the success of EFL learning within non-native settings. Hence, within the Malaysian educational context, a revisit to the Malaysian language planning and policy and EFL curriculum development is called for as an effort to alleviate if not eliminate the issues in EFL literacy, which might lend to adverse impacts not only within the educational domain, but also extended to the economic domain and beyond. The findings in this study also have implications on other EFL settings of a similar nature.

\section{References}

Abdullah. H., \& Sidek, H.M. (2012). L2 writing feedback: Alignment of instructional planning and implementation. Journal of Language Studies, 15, 15-17.

Abu Hasan Z. (2008). Peer interaction and meaning construction among EFL learners in comprehending texts in 2nd language context. Unpublished Ph.D. thesis. Faculty of Modern Languages, Universiti Putra Malaysia, Serdang.

Ambigapathy P., Liew C. L., Tan A. L., Jayagowri M., Lee B.C., \& Toh C.H. (Eds.) (2013). New Literacies: Reconstructing Language and Education. Newcastle upon Tyne: Cambridge Scholars Publishing.

Asmah, H. O. (1979). Language planning for unity and efficiency: A Study of the language status and corpus planning of Malaysia. University of Malaya: Kuala Lumpur.

Asmah, H. O. (1996). Post-imperial English in Malaysia. In J. A. Fishman, A. W. Conrad and A. Rubal-Lopez (eds.), Post-Imperial English. Status Change in Former British and American Colonies, 1940-1990 (pp. 513-533). Berlin and New York: Mouton de Gruyter.

Baharun, H., Sidek, H.M., Saad N.S.M., Idrus, M.M., Harun, H., Darmi. R, Abdullah, N., \& Ashikin, Z. (2016). The Malaysian secondary school EFL speaking curriculum: A theoretical foundation alignment analysis. International Journal of Advance Social Sciences, 2(6), 465-474.

Beck, I. L., \& McKeown, M. G. (2006). Improving comprehension with questioning the author: A fresh and expanded view of a powerful approach. Scholastic.

Course of Studies Regulation II. (1956). Cited in Foo, B. \& C. Richards. (2004). English in Malaysia. RELC Journal, 35(2), 229-240.

Education Ordinance. (1957). Malaysian Ministry of Education (MOE). Retrieved from http://www.moe.gov.my

Faizah, A. M., Zalizan, M. J., \&Norzaini, A. (2002). Selected Malaysian adult learners' academic reading strategies: A case study. Retrieved from https://doi.org/10.2167/le631.0

Foo, B., \& Richards, C. (2004). English in Malaysia. RELC Journal, 35(2), 229-240. https://doi.org/10.1177/003368820403500209

Gill, S. K. (2006). Change in language policy the reality of implementation in public universities. Current issues in language planning. Special Issue on Language Planning and Academic Communication, 7(1), 82-94. https://doi.org/10.2167/cilp083.0

Gopinathan, S. (2003). Language policy changes 1979-1997: Politics and pedagogy. In. Grabe, W. (1991). Current developments in second language reading research. TESOL Quarterly, 25(3), 375-406.

Heng C. S., \& Tan, H. (2006). English for mathematics and science: Current Malaysian language-in-education policies and practices. Language and Education, 20(4), 306-321.

Kalaverny, R. (1986). The present status of Malaysian English: The restriction phase. Singapore: RELC.

Kanagasabai, S. (1996). Proficiency in EFL: A study of Indian urban and rural learners. MEFL Thesis. University of Malaya Kuala Lumpur.

Kaplan, R. R., \& Baldauf, R. B. (1997). Language planning: From practice to theory. Clevedon: Multilingual Matters.

Kaur, N. (2006). Non-autonomy and low-English proficiency among Malaysian students: Insights from multiple perspectives. In Kamisah Ariffin, Mohd. Rozaidi Ismail, Ngo Kea Leng, \&Roslina Abdul Aziz. (Eds.), English 
in the Malaysian context (pp 21-34). Shah Alam: University Publication Centre (UPENA) UiTM.

Kaur, S. K., \& Thiyagarajah, R. (1999). The English reading habits of ELLs student in University Science Malaysia. Original ultiBASE publication. Paper presented at the Sixth International Literacy and Education Research Network Conference on Learning, Bayview Beach Resort, Penang, Malaysia 27 - 30 September 1999.

La Morgia, F. (2014). Assessing the relationship between input and strength of language development: A study on Italian-English bilingual children. In C. Silva-Corvalán\& J. Treffers-Daller (Eds.), Language dominance in 29 bilinguals: Issues of measurement and operationalization. Cambridge: Cambridge University Press.

Lee, K. S. (2004). Reading into our reading tests. In Wijayasuriya, B. \& F. Hashim (Eds.), Reading Connections (pp. 128-140). Petaling Jaya: SasbadiSdn Bhd.

LeVasan, M. (1983). A critique on the current English reading programme of undergraduates of UKM. MA Thesis. University of Malaya: Kuala Lumpur.

Mahathir, M. (1986). The Challenge. Petaling Jaya: Pelanduk Publication.

Mohd. Noor., N. (2006). Reading academic text: Awareness and experiences among university EFL learners. GEMA Online $^{\mathrm{TM}}$ Journal of Language Studies, 6(2), 65-78.

Mustapha, Z. (1995). Schemata as a reading strategy. (ERIC Document Reproduction Service No ED 415 497).

Nambiar, G. R. (2005). Why don't they read the way they should? Online submission. (ERIC Document Reproduction Service No ED 4903379). Retrieved from http://www.google. com/search?hl=en\&q=radha+nambiar-gopal

Nambiar, R.M.K., Ibrahim N., \& Krish, P. (2008). Penggunaan strategi pembelajaran bahasa dalam kalangan pelajar Tingkatan Dua. Journal e-Bangi, 3(3), 1-17.

National Language Act. (1971). Malaysian Ministry of Education (MOE). Retrieved from http://www.moe.gov.my.

O'Neill, M., \& Chapman, A. (2015). Globalisation, internationalization \& and English language: Studies of education in Singapore, Malaysia and Australia (online). Education Research and Perspectives, 42, 1-24.

Pennycook, A. (1994). The cultural politics of English as an international language. New York: Longman.

Phillipson, R. (2009). Linguistic imperialism. Oxford: Oxford University Press.

Place, S., \& Hoff, E. (2011). Properties of dual language exposure that influnec a two-year-old's bilinguals proficiency. Child Development, 82, 1834-1849. https://doi.org/10.1111/j.1467-8624.2011.01660.x

Ponniah, K.S. (1993). Improving academic reading ability of EFL students at tertiary level. Unpublished Doctoral Dissertation. University of Malaya, Kuala Lumpur.

Powell, R. (2002). Language planning and the British empire: Comparing Pakistan, Malaysia, and Kenya. Current Issues in Language Planning, 3(3), 205-279. https://doi.org/10.1080/14664200208668041

Ramaiah, M., \& Nambiar, M. K. (1993). Do undergraduates understand what they read: An investigation into the comprehension monitoring of EFL students through the use of textual anomalies. Journal of Educational Research, 15, 95-106.

Razak Committee. (1955). Razak Report of the Education Committee. Ministry of Education Malaysia. Retrieved from http: //www.moe.gov.my.

Ridge, S. G. M. (2004). Bangsa Malaysia and recent English language policy. Current Issues in Language Planning, 5(4), 407-423. https://doi.org/10.1080/14664200408668266

Saad, N.S.M., Sidek, H.M., Baharun, H., Idrus, M.M., \& Yunus. M.Y. (2016b). A Conceptual Framework to Explore the English Language Learning Experiences of International Students in Malaysia. International E-journal of Advances in Social Sciences, 2(6), 453-464.

Saad, N.S.M., Yamat, Y., Sidek, H.M., Baharun, H., \& Idrus, M.M. (2016a). Acts of Agency in English Language Learning Experience. International E-journal of Advances in Social Sciences, 2(6), 733- 746. https://doi.org/10.18769/ijasos.281042

Shih, M. (1992). Beyond comprehension exercises in the EFL academic reading class. TESOL Quarterly, 26(2), 289-317. https://doi.org/10.2307/3587007

Shukor et al. (1993). Towards ESP programmes in technical and vocational institutions in Malaysia. (ERIC 
Document Reproduction Service No. ED 369 266).

Sidek, H. M. \& Abdullah, H. (2013). EFL Reading Comprehension and Preparation For Higher Education: A Textbook Analysis. Journal of Teaching and Education, 24(4), 425-435.

Sidek, H. M. (2010a). An analysis of the EFL secondary reading curriculum in Malaysia: approaches to reading and preparation for higher education. Doctor of Philosophy, University of Pittsburgh.

Sidek, H. M. (2010c). Reading Instruction: Theory and Practice. Nilai: Usim Publisher.

Sidek, H. M. (2012a). EFL reading instruction: Communicative task-based approach. International Journal of Instruction, 5(2), 109-128.

Sidek, H. M. (2012b). EFL textbook analysis: A case study. Language and Literacy Journal, 14(3), 27-45. https://doi.org/10.20360/G2HP4J

Sidek, H. M. (2013a). A Cross-Linguistic Study of Vocabulary Knowledge and Second Language Reading Development. Frontiers of Language and Teaching, 4, 178-185.

Sidek, H. M. (2013b). Communicative reading instructional approach: A Curriculum Review. International Journal of Interdisciplinary Educational Studies, 7(1), 9-20. https://doi.org/10.18848/2327-011X/CGP/v07i01/53286

Sidek, H. M. (2014). English Language Reading Preparation for Higher Education: An Evaluation of the Form Four English Language Textbook and Instructional Design. Journal of Social Science and Humanities (PERTANIKA), 22(2), 539-558.

Sidek, H. M., Abdullah, H., \& Rahim, H.A. (2013). Reading Curriculum and Instructional Analysis: Preparation for Academic Literacy at Higher Institutions. Journal of Teaching and Education, 2(2), 389-396.

Sidek, H., \& Rahim, H. (2014). EFL reading instruction: Alignment of curriculum implementation. Paper presented at the 6th International Conference on Education and New Learning Technologies, Barcelona, Spain.

Sidek, H.M. (2010b). Reading Attitudes a Case Study in Malaysia. Annals of Language Teaching, (pp. 209- 215), Boca Raton, Florida: Universal-Publishers.

Sidek, H.M. (2011). Methods of EFL secondary reading instruction: Preparation of higher education. International Journal of Humanities and Social Science, 1(3), 181-191.

Sidek, H.M. (2012c). Reading Attitudes: A Case Study in Malaysia. Proceedings of the 2009 International Online Language Conference (IOLC 2009), p.209. Annals of Language and Learning: BocaRaton: Universal Publisher

Sidek, H.M. (2012d). EFL Language Learning Personality Traits and Instruction. International Journal of Learning, $18(5), 255-272$.

Sidek, H.M., H. Abdullah, H.A. Rahim \& Mohamed, Y. (2014). EFL Reading Instruction: Alignment of Curriculum and Implementation. Procedia-Social and Behavioral Sciences, 118, 442-449. https://doi.org/10.1016/j.sbspro.2014.02.060

Tsui, A. B. M., \& Tollefson, J. W. (eds.). (2006). Language policy, culture, and identity in Asian contexts. Lawrence Erlbaum, Mahwah, NJ.

Wahi, W. (2013). Reading in Engineering: Understanding Engineering students' English language academic literacies. International Proceedings of Economics Development and research: Languages, Literature and Linguistics III, 68, 107-112.

Wahi, W. (2015). English Language Literacies of Undergraduate Students in Malaysia's Culturally and Linguistically Diverse Environment: Casualties of National Language Policies and Globalisation? Educational Research and Perspectives, 42, 329-362.

Wahi, W., O'Neill, M., \& Chapman, A. (2012). Exploring Academic Literacies of EFL Undergraduate Students. International Conference: Innovative Research in a Changing and Challenging World Conference Proceedings. Phuket. 